\title{
Hubungan Peran Suami dan Sikap Ibu Terhadap Pemakaian Kontrasepsi Implant Pada Akseptor KB Di Rumah Sakit Bhayangkara Makassar Tahun 2015
}

\author{
Risma Putri Utama \\ Sekolah Tinggi Ilmu Kesehatan Husada Mandiri Poso \\ Email : rismaputri.utama@yahoo.co.id
}

\begin{abstract}
Background: the use of a cotraception tool is a shared responsibility between husband and wife. The results of the study showed that $65 \%$ of women wanted the role of a larger husband in the selection of contraceptive devices. An implant contraceptive is one of the contraceptives in the form of implants made of a kind of silatic rubber which contains hormones attached to the upper arm. Support and attitude of a person regarding implants will cause action on the use of implants. Objective: To determine the relationship of the role of the husband and the attitude of the mother to the use of implant contraception in family planning acceptors at Bhayangkara Makassar Hospital in 2015. Methods: The type of research was descriptive analytic. The population in this study were all mothers who used implant contraception in the family planning room of Bhayangkara Hospital in Makassar as many as 184 people. Sampling with accidental sampling technique amounted to 65 samples. Data were analyzed using Chi-Square Statistical Test with p-Value $<0.05)$. Results: There is a relationship between the role of husband and implant contraceptive use $(\mathrm{P}-$ Value $=0.036<0.05)$, there is a relationship between maternal attitudes and implant contraceptive use $(\mathrm{P}-\mathrm{Value}=0.002<0.05)$. Conclusion: the role of the husband and the mother's attitude are related to the use of implant contraception.
\end{abstract}

Keywords: husband's role, mother's attitude, implant contraception 


\begin{abstract}
Abstrak
Latar Belakang : penggunaan alat kotrasepsi adalah tanggung jawab bersama antara suami dan istri. Hasil studi menunjukkan $65 \%$ wanita menginginkan peran dari suami yang lebih besar dalam pemilihan alat kontreasepsi. Alat kontrasepsi implant adalah salah satu alat kontrasepsi yang berupa susuk yang terbuat dari sejenis karet silatik yang berisi hormon yang dipasang pada lengan atas .Dukungan dan sikap seseorang mengenai implant akan menimbulkan tindakan terhadap pemakaian implant tersebut. Tujuan: Untuk mengetahui hubungan peran suami dan sikap ibu Terhadap Pemakaian Kontrasepsi Implant Pada Akseptor KB Di Rumah Sakit Bhayangkara Makassar Tahun 2015. Metode Penelitian : jenis penelitin adalah deskriptif analitik. Populasi dalam penelitian ini yaitu seluruh ibu yang memakai kontrasepsi di ruangan keluarga berencana Rumah Sakit Bhayangkara Makassar sebanyak 184 orang. Pengambilan sampel dengan teknik accidental Sampling berjumlah 65 sampel. Data dianalisis dengan menggunakan Uji statistik ChiSquare dengan $p$-Value $<0,05)$. Hasil:Terdapat hubungan antara peran suami terhadap pemakaian kontrasepsi implant $(P$-Value $=0,036<0,05)$, terdapat hubungan antara sikap ibu dengan pemakaian kontrasepsi implant $(P$-Value $=0,002<0,05)$. Kesimpulan: peran suami dan sikap ibu berhubungan dengan pemakaian kontrasepsi implant.
\end{abstract}

Kata Kunci : peran suami, sikap ibu, kontrasepsi implant

\title{
PENDAHULUAN
}

Masalah utama dihadapi di Indonesia saat ini khususnya di dalam kependudukan yaitu masalah pengendalian tingkat kelahiran dan usaha penurunan tingkat pertambahan penduduk yang kemudian mempersulit usaha peningkatan dan pemerataan kesejahteraan rakyat dimana semakin tinggi pertumbuhan penduduk maka semakin kuat usaha yang dilakukan untuk mempertahankan kesejahteraan rakyat. Berbagai upaya yang dilakukan pemerintah Indonesia untuk memperlambat pertumbuhan penduduk yang terus meningkat, antara lain melaksanakan program keluarga berencana (KB) yang bertujuan untuk meningkatkan kesejahteraan Ibu dan Anak serta menunjukkan norma keluarga kecil bahagia dan sejahtera. Dalam usaha pencapaian sasaran tersebut, maka disusun beberapa arahan kebijakan, salah satunya yaitu peningkatan pemakaian kontrasepsi yang lebih efektif serta efisien dalam jangka waktu yang panjang. (1)

Menurut World Health Organization (WHO) penggunaan alat kontrasepsi adalah tindakan yang membantu individu atau pasangan suami istri untuk mendapatkan objek-objek tertentu, 
menghindari kelahiran yang tidak diinginkan, mendapatkan kelahiran yang memang diinginkan, mengatur interval diantara kehamilan, mengontrol waktu saat kelahiran dalam hubungan dengan umur suami istri, dan untuk menentukan jumlah anak dalam keluarga (2).

Data dari WHO menunjukkan bahwa pengguna alat kontrasepsi implant di seluruh dunia masih di bawah alat kontrasepsi suntik, pil, dan IUD, terutama di negara-negara berkembang. Persentase pengguna alat kontrasepsi suntik yaitu 35,3\%, pil yaitu 30,5\%, IUD yaitu 15,2\% sedangkan implant di bawah $10 \%$ yaitu 7,3\%, dan alat kontrasepsi lainnya sebesar 11,7\%. (3)

Badan Kependudukan dan Keluarga Berencana Nasional (BKKBN) pada tahun 2013 mendapatkan 8.500.247 PUS (Pasangan Usia Subur) yang merupakan peserta KB baru, dengan rincian pengguna kontrasepsi suntik 4.128.115 peserta $(48,56 \%)$, pil 2.261.480 peserta $(26,60 \%)$, implan 784.215 peserta $(9,23 \%)$, kondom 517.638 peserta(6,09\% ), alat kontrasepsi dalam rahim 658.632 peserta (7,75\%), MOW (metode operasi wanita) 128.793 peserta (1,52\%), MOP (metode operasi pria) 21.374 peserta $(0,25 \%)$, dimana dari data di atas menunjukkan yang terbanyak digunakan adalah metode kontrasepsi suntik (4).

Salah satu metode kontrasepsi yang efektif yaitu implant. Di Indonesia alat kontrasepsi ini sudah mulai diteliti dan dikembangkan sejak tahun 1981. Dan di berbagai negara implant telah digunakan oleh lebih dari 10 ribu wanita. (5). Dalam pelaksaan pemilihan kontrasepsi khususnya implant ada beberapa faktor yang mempengaruhi antara lain peran suami dan sikap ibu. Menurut teori Green dan Kreuter (2005) perilaku seseorang dipengaruhi oleh 3 fakor yaitu faktor predisposisi antara lain sikap, faktor pemungkin antara lain lingkungan fisik, dan faktor penguat antara lain dukungan dan peran pasangan. (6)

Berdasarkan data yang diperoleh dari Dinas Kesehatan Provinsi Sulawesi Selatan pada tahun 2013 pencapaian akseptor KB yaitu 1.001.619 peserta, dan untuk metode akseptor pada tahun 2014, jenis akseptor suntik 442.366 peserta $(44,17 \%)$, pil 315.720 peserta $(31,25 \%)$, implant sebanyak 110.082 peserta (10,99\%). Kondom 69.160 peserta (6,9\%), Intra Uterine Device (IUD) 45.167 peserta (4,51\%), Medis Opera;si Wanita (MOW) 17.386 peserta $(1,7 \%)$ serta Medis Operasi Pria (MOP) 1.738 peserta $(0,17 \%)$. (7).

Tujuan dari penelitian ini yaitu ingin mengetahui bagaimana peran suami dan sikap ibu dalam penggunaan kontrasepsi implant. Sehingga dengan demikian hambatan hambatan dalam 
pemilihan kontrasepsi dapat teratasi dan program $\mathrm{KB}$ dapat terlaksana sesuai dengan pencapaiannya.

\section{METODE}

Jenis penelitian ini merupakan penelitian deskriptif analitik dengan pendekatan cross sectional study dimana penelitian ini bertujuan untuk mengetahui hubungan peran suami dan sikap ibu terhadap pemakaian kontrasepsi implant pada Akseptor KB Di Rumah Sakit Bhayangkara Makassar Tahun 2015. Populasi dalam penelitian ini yaitu seluruh ibu yang memakai kontrasepsi di ruangan Keluarga Berencana Rumah Sakit Bhayangkara Makassar sebanyak 184 orang. Sampel dalam penelitian ini berjumlah 65 sampel yang diambil melalui teknik accidental Sampling dan memenuhi kriteria sebagai berikut yaitu : 1) Akseptor KB yang menggunakan kontrasepsi implant 2) Bersedia menjadi responden, 3) bisa baca tulis dan berkomunikasi dengan baik. Data dianalisis dengan menggunakan uji statistic Chi-Square.

\section{HASIL}

Tabel 1. Distribusi Pemakaian alat kontrasepsi implant pada Akseptor KB Di Rumah Sakit Bhayangkara Makassar

\begin{tabular}{ccc} 
& Tahun 2015 & \\
\hline $\begin{array}{c}\text { Pemakaian alat kontrasepsi } \\
\text { implant }\end{array}$ & $\begin{array}{c}\text { Frekuensi } \\
(\mathbf{n})\end{array}$ & $\begin{array}{c}\text { Presentase } \\
(\mathbf{\%})\end{array}$ \\
\hline KB jangka panjang & 24 & 36,99 \\
KB jangka pendek & 41 & 63,01 \\
Jumlah & 65 & 100 \\
\hline
\end{tabular}

Tabel 1 menunjukkan bahwa dari 65 sampel ibu akseptor KB di Rumah Sakit Bhayangkara Makassar Tahun 2015, terdapat 24 (36,99\%) ibu yang menggunakan KB jangka panjang dan 41 $(63,01 \%)$ ibu yang menggunakan KB jangka pendek.

Tabel 2. Gambaran Peran suami pada Akseptor KB Di Rumah Sakit Bhayangkara Makassar Tahun 2015

\begin{tabular}{ccc}
\hline Peran suami & Frekuensi (n) & $\begin{array}{c}\text { Presentase } \\
(\boldsymbol{\%})\end{array}$ \\
\hline Cukup & 35 & 53,8 \\
Kurang & 30 & 46,2 \\
\hline
\end{tabular}




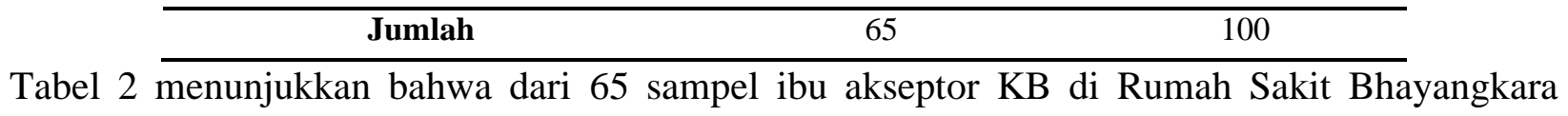

\begin{tabular}{|c|c|c|c|c|c|c|c|}
\hline \multirow{3}{*}{ Peran Suami } & \multicolumn{4}{|c|}{$\begin{array}{c}\text { Pemakaian kontrasepsi } \\
\text { implant }\end{array}$} & \multirow{2}{*}{\multicolumn{2}{|c|}{ jumlah }} & \multirow{3}{*}{ P-Value } \\
\hline & \multicolumn{2}{|c|}{$\begin{array}{l}\text { KB jangka } \\
\text { panjang }\end{array}$} & \multicolumn{2}{|c|}{$\begin{array}{l}\text { KB jangka } \\
\text { pendek }\end{array}$} & & & \\
\hline & $\mathrm{f}$ & $\%$ & $f$ & $\%$ & $f$ & $\%$ & \\
\hline Cukup & 17 & 48,6 & 18 & 51,4 & 35 & 100 & \\
\hline kurang & 7 & 23,3 & 23 & 76,7 & 30 & 100 & $\mathrm{P}=0,036$ \\
\hline jumlah & 24 & 36,9 & 41 & 63,1 & 65 & 100 & \\
\hline
\end{tabular}

Makassar Tahun 2015, terdapat $35(53,8 \%)$ ibu yang peran suaminya cukup dan $30(46,2 \%)$ ibu yang peran suaminya kurang.

Tabel 3. Gambaran sikap ibu Akseptor KB Di Rumah Sakit Bhayangkara Makassar Tahun 2015

\begin{tabular}{ccc}
\hline Sikap ibu & $\begin{array}{c}\text { Frekuensi } \\
(\mathbf{f})\end{array}$ & $\begin{array}{c}\text { Presentase } \\
(\boldsymbol{\%})\end{array}$ \\
\hline Cukup & 27 & 41,55 \\
Kurang & 38 & 58,45 \\
Jumlah & 65 & 100 \\
\hline
\end{tabular}

Tabel 3 menunjukkan bahwa dari 65 sampel ibu yang menjadi akseptor KB Rumah Sakit Bhayangkara Makassar Tahun 2015 terdapat 27 (41,55\%) ibu yang memiliki sikap yang cukup dan $38(58,45 \%)$ ibu yang memiliki sikap kurang.

Tabel di atas menunjukkan hubungan antara peran suami dengan pemakaian kontrasepsi implant bahwa responden memiliki peran suami kurang yaitu sebanyak 30 orang Masing-masing yang menggunakan KB jangka pendek yaitu 23 (76,7\%) dan yang menggunakan KB jangka panjang sebanyak 7 (23,3\%) kemudian dari 35 orang yang memiliki peran suami cukup 18 responden $(51,4 \%)$ yang menggunakan $\mathrm{KB}$ jangka pendek dan 17 (48,6\%) yang menggunakan KB jangka panjang. 
Berdasarkan hasil uji statistik. Chi-Square di peroleh nilai $\mathrm{P}=0,036$ ini berarti $\mathrm{p}<0,05$ sehingga hipotesis alternatif (Ha) di terima dan hipotesis Nol (HO) ditolak dan di interpretasikan bahwa ada hubungan antara peran suami dengan penggunaan kontrasepsi implant.

Tabel 5 : Hubungan antara sikap ibu dengan pemakaian kontrasepsi implant pada akseptor KB di Rumah Sakit Bhayangkara Makassar Tahun 2015

\begin{tabular}{ccccccccc}
\hline & \multicolumn{3}{c}{ Pemakaiankontrasepsi } & & & \\
\cline { 2 - 4 } Sikap ibu & \multicolumn{2}{c}{$\begin{array}{c}\text { KB jangka } \\
\text { panjang }\end{array}$} & \multicolumn{2}{c}{$\begin{array}{c}\text { KB jangka } \\
\text { pendek }\end{array}$} & & Jumlah & P-Value \\
& $\mathrm{f}$ & $\%$ & $\mathrm{f}$ & $\%$ & $\mathrm{f}$ & $\%$ & \\
Cukup & 16 & 59,3 & 11 & 40,7 & 27 & 100 & \\
Kurang & 8 & 21,1 & 30 & 78,9 & 38 & 100 & 0,02 \\
Jumlah & 24 & 36,9 & 41 & 63,1 & 65 & 100 & \\
\hline
\end{tabular}

Tabel di atas menunjukkan hubungan antara sikap ibu dengan pemakaian kontrasepsi implant bahwa sebagian responden yang memiliki sikap kurang yaitu 38 orang dimana masing-masing yang menggunakan KB jangka pendek yaitu 30 (78,9\%) dan yang menggunakan KB jangka panjang sebanyak 8 (21,1\%) kemudian dari 27 orang yang memiliki sikap dalam ketegori cukup terdiri dri 11 orang $(40,7 \%)$ yang menggunakan KB jangka pendek dan 16 orang $(59,3 \%)$ yang menggunakan KB jangka panjang.

Berdasarkan hasil uji statistik Chi-Square diperoleh nilai $\mathrm{p}=0,02$ ini berarti $\mathrm{p}<0,05$ sehingga hipotesis alternatif (Ha) di terima dan hipotesis Nol (HO) ditolak dan di 
interpretasikan bahwa ada hubungan antara sikap ibu dengan penggunaan kontrasepsi implant.

\section{PEMBAHASAN}

\section{Hubungan antara peran suami dengan pemakaian kontrasepsi implant pada} akseptor KB di Rumah Sakit Bhayangkara Makassar Tahun 2015

Peran suami sangat diperlukan dalam melaksanakan Keluarga Berencana dimana salah satunya dalam pemilihan alat kontrasepsi untuk pasangan. Peran suami dalam keluarga yaitu sebagai motivator dimana suami memberikan dorongan atau dukungan kepada anak maupun istri dengan tujuan unuk membangkitkan, membangun kualitas, membentuk dan mencapai tujuan hidup yang lebih baik. Kuatnya motivasi yang diberikan dalam keluarga dapat meningkatkan daya potensi lebih berkembang (8).

Dukungan dan peran suami merupakan salah satu faktor penguat yang dapat mempengaruhi seseorang dalam berperilaku. Khususnya dalam pemilihan alat kontrasepsi harus membutuhkan partisipasi atau dukungan dari suami karena hal ini brhubungan dengan organ reproduksi dari kedua pihak. (9)

Dalam penelitian ini lebih banyak suami yang memiliki peran cukup dalam pemakaian kontrasepsi implant. Peran suami terhadap istri dalam pemilihan alat Kontrasepsi sangat penting dimana suami dapat berperan sebagai motivator, edukator, dan sebagai Fasilitator. Hasil penelitian ini sejalan dengan penelitian yang dilakukan oleh Masuffa (2014) tentang pemilihan alat kontrasepsi implant. dimana 48, $2 \%$ peran suami berada dalam kategori cukup. (10) 
Dalam penelitian ini diperoleh sebagian besar responden yang memiliki peran suami kurang memilih kotrasepsi jangka pendek. Hal ini disebabkan karena peran suami masih kurang baik sebagai edukator dalam hal memberikan informasi kepada istri tentang alat kontrasepsi, dan peran sebagai pemberi dirongan dan motivasi kepada istri dan sebagai fasilitator dalam hal antara lain dukungan biaya untuk kontrasepsi.

Hal ini Sejalan dengan pendapat Dagun (2005), bahwa suami merupakan seorang yang pertama dan utama dalam memberi pertolongan kepada istri sebelum pihak lain memberikan dorongan dan perhatian seorang suami terhadap istri yang akan memilih KB. (11)

Dalam penelitian ini diperoleh adanya hubungan antara peran suami dengan pemakaian kontrasepsi implant. Penelitian ini sejalan dengan penelitian ysng dilakukan oleh Masuffa (2014) tentang hubungan peran suami dengan pemilihan alat kontrasepsi implant di BPM ari Suprapti Candi sidoarjo yang menemukan adanya hubungan antara peran suami dengan pemilihan alat kontrasepsi implant. (10).

\section{Hubungan Antara Sikap Ibu Dengan Pemakaian kontrasepsi implant pada akseptor KB di Rumah Sakit Bhayangkara Makassar Tahun 2015}

Sikap merupakan reaksi atau respons seseorang yang masih tertutup terhadap suatu stimulus atau objek. dimana sikap ini berhubungan dengan pengetahuan dan pendidikan seseorang (12). Sikap juga merupakan respon tertutup terhadap stimulus atau objek tertentu yang melibatkan faktor pendapatan dan emosi yag bersangkutan (senang tidak senang, setuju tidak setuju, baik-tidak baik, dan sebagainya).(13)

Menurut Badan Koordinasi Keluarga Berencana (BKKBN) yang menyatakan bahwa pegetahuan seseorang individu tentang keluarga berencana dan alat kontrasepsi yang tersedia sangat menentukan proses penerimaan dan penggunaan seseorang terhadap penggunaan implan sehingga dapat dikatakan penggunaan implant tidak hanya dipengaruhi oleh pengetahuan tetapi juga dipengaruhi ketersediaan alat kontrasepsi dan juga sikap dan kesadaran untuk menggunakan implan. (14)

Dalam peneletian ini sebagian besar responden memiliki sikap yang kurang dalam penggunaan kontrasepsi implant. Hal ini disebabkan karena kurangnya informasi yang 
diberikan kepada ibu tentang metode kontrasepsi implant. Dalam penelitian ini diperoleh sebagian besar responden yang memiliki sikap yang kurang menggunakan metode kontrasepsi jangka pendek. Pada penelitian Ruri Astuti 2014 di Rumah Sakit Wilasa Citarum Semarang memperlihatkan bahwa sikap ibu kategori cukup yang mengunakan kontrasepsi implant sbeanyak 22 orang (81,5\%) dan akseptor yang sikap ibu kurang penggunaan kontrasepsi implant sebanyak 5 orang $(18,5 \%)$

Paparan sumber informasi tentang MKJP (medote kontrasepsi jangka pendek) berhubungan dengan minat seseorang terhadap MKJP. Paparan sumber dapat mempengaruhi banyak atau sedikitnya pengetahuan yang dapat diakses oleh individu. Dimana Semakin banyaknya paparan sumber informasi dapat disejajarkan dengan semakin banyaknya individu tersebut menerima promosi kesehatan (15).

Dalam penelitian ini diperoleh adanya hubungan antara Sikap Ibu Dengan Pemakaian kontrasepsi implant. Penelitian ini sejalan dengan penelitian yang dilakukan oleh Imbroni, dkk (2009) dimana hasil penelitiannya menemukan ada hubungan yang signifikan antara sikap ibu mengenai implan terhadap penggunaan implan. (16). Dalam teori yang dikemukkan oleh Branon, Defleur, Westie, dan Wicker menyatakan bahwa adanya indikasi hubungan yang kuat antara sikap dan perilaku(17). Sehingga dari hasil penelitian ini dapat disimpulkan bahwa sikap positif seseorang mengenai implan akan menyebabkan suatu tindakan menggunakan kontrasepsi implant.

\section{KESIMPULAN}

Berdasarkan hasil penelitian ini maka dapat disimpulkan bahwa : 1) terbanyak responden pengguna akseptor KB implant memiliki peran suami yang cukup. 2) terbanyak responden memiliki sikap yang kurang terhadap penggunaan KB Implant. 3) peran dan sikap ibu berhubungan dengan pemakaian kontrasepsi implant.

\section{DAFTAR PUSTAKA}

1. BKKBN, 2005. Jumlah Peserta KB Aktif Menurut Jenis Kontrasepsi. Kota Padang Tahun 2005.

2. Hartanto, Hanafi. Keluarga Berencana dan Kontrasepsi. Cetakan Kelima . Jakarta: Pustaka Sinar Harapan. 2013.

3. Safrina. Pengaruh Penggunaan Kontrasepsi Terhadap Pasangan Usia Subur di Kecamatan Tanjung Rejo. Skripsi FKM Universitas Sumatera Utara. 2012 
4. Kemenkes RI. Profil Kesehatan Indonesia. Jakarta: Kementrian Kesehatan Republik Indonesia, 2015 .

5. Mochtar, Rustam. Sinopsis Obstetry Jilid I. EGC: Jakarta. 1998

6. Green., Lawrence W \& Kreuter. Health Program Planning. An.Educational Ecological Approach. New York: the MeGraw-HiII . Companies. Inc. 2005

7. Dinas Kesehatan Provinsi Sulawesi Selatan. Profil Kesehatan Provinsi Sulawesi Selatan Tahun 2013, Makassar. 2013

8. Taslim, Abdullah .Potret Suami Ideal dalam Rumah Tangga. Kendari: Muslim.Or.Id. 2015

9. Adhyani, Anisa Rahma. Faktor-faktor yang Berhubungan dengan Pemilihan Kontrasepsi NonIUD pada Akseptor KB Wanita Usia 20-39 Tahun. Program Pendidikan Sarjana Kedokteran Universitas Diponegoro Semarang: Skripsi. 2011.

10. Massufa. Hubungan Peran Suami Dengan Pemilihan Alat Kontrasepsi Implant Di Bpm Ari Suprapti Candi. Sidoarjo. 2014

11. Dagun, S.M. Psikologi Keluarga: Peranan Ayah Dalam Keluarga. Cetakan Kedua. Jakarta: Rineka Cipta. 2005

12. Proverawati. Panduan Memilih Kontrasepsi. Yogyakarta: Nuha Medika 2010

13. Notoatmodjo, S. Metodologi Penelitian Kesehatan. Jakarta. Penerbit EGC. 2010

14. BKKBN. Keluarga Berencana, Kesehatan Reproduksi, Gender dan Pembangunan Kependudukan. BKKBN, Jakarta. 2003

15. Rogers, E. Difussion of Innovation 6th Edition. New York: Simon and Schusters. 2008

16. Imroni, Medias., Fajar, Nur Alam., Febry, Fatmalina. Faktor-Faktor Yang Berhubungan Dengan Penggunaan Implan Di Desa Parit Kecamatan Indralaya Utara Kabupaten Ogan Ilir. Tahun 2009

17. Azwar, Saifuddin. Sikap Manusia, Teori dan Pengukurannya. Pustaka Pelajar, Yogyakarta. 1995 
